\title{
Change Detection of Land Cover at Flood Potential Areas using Multitemporal Image Data in East Jakarta City
}

\author{
Abdul Wahid Hasyim \\ Department of Regional and Urban \\ Planning, Universitas Brawijaya, Jl. \\ MT. Haryono 167, Malang City, \\ East Java, Indonesia, 65145
}

\author{
Dimas Danur Cahya \\ Department of Regional and Urban \\ Planning, Universitas Brawjaya, Jl. \\ MT. Haryono 167, Malang City, \\ East Java, Indonesia, 65145
}

\author{
Ismu Rini Dwi Ari \\ Department of Regional and Urban \\ Planning, Universitas Brawijaya, Jl. \\ MT. Haryono 167, Malang City, \\ East Java, Indonesia, 65145
}

\begin{abstract}
East Jakarta City is one of 6 cities / regencies in the. The city of East Jakarta as one of the cities in the Special Capital Province of Jakarta has a significant growing population. Changing of land cover might result on flood disaster in related with the growth of population. Main purpose of the study is to determine variable that influence the flood height of an area with imagery data in the period of four decades $-1990,2000,2020$, and 2020. The first step uses land cover classification analysis to identify land cover in the City of East Jakarta. Then, land use analysis uses change detection methods to determine the changes that occur in each land class. The second step of spatial analysis with the ordinary least square method and geographical weighted regression covering 6 variables - flood height, rainfall, contour, river water level, land cover and population density, in order to find out the variables that influence flooding in the research area. The land cover in the East Jakarta City in the period of 1990-2020 had a significant changed, especially for increasing of built-up area. Since total of the area is fixed, the wider built-up area means the lessen areas for other land uses such as vegetation, water body and un-built-up areas. Then, variables that affect flooding in each district are differ for each district. For district of Cakung, Makasar, Kramat Jati, Pulo Gadung is related to contour of the region. Then, at district of Ciracas, Cipayung, Duren Sawit are due to area of land developed. Next, at Jatinegara and Pasar Rebo Districts are about population density, and at Matraman District is rainfall variable. Understanding cause of the flood might give a better approach on propose a flood management disaster strategy that it might conduct in the future reseach.
\end{abstract}

Keywords-Flood, remote sensing, land cover classification, change detection

\section{INTRODUCTION}

Rapid growth of population can derive a problem in the city. City of East Jakarta has annual growth population rate at about $4.2 \%$ in the period of 2010-2019 [1]. Changing land use has also changing groundwater compartments. At about $40 \%$ of the population in Jakarta depend on groundwater resources, wherein this percentage is higher than ground water supply of upstream cities such as Bogor City and Depok City, which is water deficit occurred due to imbalance between abstraction and aquifer replenishment [2]. Flood is events to be inundated by a ridge of land that usually dried. Flood can be caused by rising sea levels as well as the volume of water displaced due to the inability of the absorption of water into the ground [3].

The East Jakarta is the 1st city with the highest disaster risk index value and the 2 nd city with the highest flood disaster risk index value in DKI Jakarta Province [4]. Jakarta has experienced many severe river flood events due to heavy rains, especially in 1996, 2002, 2007, 2013 and 2014 [5]. In particular, the floods that occurred in January 2013 resulted with 40 deaths, 45,000 refugees, and substantial economic damages. Flooding in February 2007 also caused extensive economic losses, increasing between 4.1 and 7.3 trillion IDR [6]. The floods in 2013 caused a loss of 15 billion IDR, and the disasters which struck in 2014 reached 100 million IDR per day [7].

Potential flood management efforts include 4 important aspects, namely i) potential for philosophical, ii) structural, iii) non-structural, and iv) socio-cultural handling [8]. The potential for handling philosophy is housing settlement revitalization and housing relocation in the flood-prone areas. The potential structural treatments consist of normalization, build reservoir, control dams, retaining dams, absorption wells, and bio pores. The potential of nonstructural measures comprises conservation and rehabilitation of forests and land in watersheds, purchase of land to expand conservation land and forest colonies. The potential for handling socio-culture is strengthening of groups and community cadres who care about environment, community assistance in behave pro environmental conservation. Therefore, it is important for this research to identify and analyze land cover, detect land cover changes and investigate spatial relationship between land cover and potential flood areas in the East Jakarta City to develop a sustainable liveable city.

\section{METHOD}

There are two primary data for the study consist of i) Landsat 5 TM imagery data for year 1990, Landsat 7 ETM + in 2000, 2010, and ii) Landsat 8 OLI TIRS imagery for year 2020. Image data that is used is May imagery with a percentage of cloud cover $0 \%$. The six variables are flood height, rainfall, area height, river water level, land cover area, and population density. Then, the analytical methods are i) land cover classification, ii) land cover change (change 
detection), iii) ordinary least square and iv) geographically weighted regression spatial analysis.

\section{A. Analysis of Land Cover Classification}

Land cover refers to natural and artificial objects found on the surface of the earth, all of which can be observed by remote sensing. The analysis that is used in the study is the supervised classification. The maximum likelihood method considers the average value and the inter-class and channel safety (covariance) [9]. Then, the Maximum Likelihood Method based on the normal distribution (Gaussian) which estimates the probability function of each class [10].

\section{B. Analysis of Land Cover Change (change detection)}

Land cover change is the process of changing the area of an area either increasing or decreasing on a land cover and use [11]. This can be influenced by natural processes such as influence of climate, volcanic eruption, sea-level changes, environment, and others [12].

Among the global thresholding methods, the Otsu variant class model is the most widely used. This model looks for the optimal threshold by maximizing variance between classes. This model is nonparametric, without supervision and can choose the threshold automatically. Change detection can be divided into two forms, namely in the form of increase and in the form of reducing/decreasing [13]. Information on land cover change is used as one of the data to determine the characteristics of an area so that the direction of planning to be carried out is better.

\section{Ordinary Least Square and Geographically Weighted Regression Spatial Analysis}

The most widely known and applied regression technique is ordinary least squares (OLS). In the spatial regression realm, the OLS technique produces a global regression model from the area of observation. The global regression model is an introduction to spatial regression that produces local models [14].

\section{RESULT AND DISCUSSION}

\section{Overview of East Jakarta}

The East Jakarta City is one of the cities in DKI Jakarta Province which has 10 districts, namely Cakung, Cipayung, Ciracas, Duren Sawit, Jatinegara, Kramat Jati, Makasar, Makasar, Matraman, Pasar Rebo, and Pulo Gadung as can be seen in Figure 1. Administrative boundaries are as follows: City

North Side : Central Jakarta City and North Jakarta

Southern Side: Bogor Regency, West Java

Eastside : South Jakarta City

Westside : Bekasi City, West Java

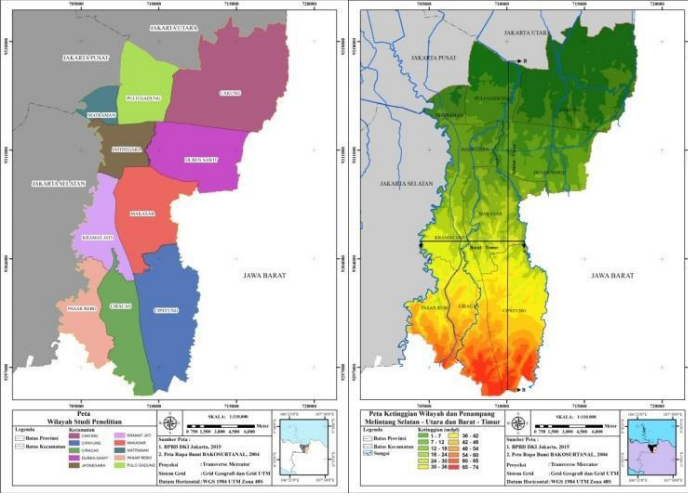

Fig. 1 Map of the Research Study Area and Area Altitude

Figure 1 depicts the height of altitude of the area that can be categorized into three groups. Firstly, at about 20,98\% (3.944,9 Ha) lies at the height of $1-7$ meter above seal level, and there is the smallest percentage area lies at the height of $65-74$ meter above sea level $(2,3 \%$ or $432,5 \mathrm{Ha})$. Then, majority of it lies at $1-18$ meter above sea level $(52,33 \%$ or 9.839,6 Ha).

Total number of populations of the area are 2.937.859 inhabitants within total area of $18.803 \mathrm{Ha}$ [15]. The average population density is about 15,624 people/Ha, with the most densely populated is Matraman (31,112 people/Ha). Into more detail, it can be seen in Table 1 .

TABLE I. POPULATION NUMBER AND DENSITY

\begin{tabular}{cccc}
\hline District & $\begin{array}{c}\text { No. of } \\
\text { Population } \\
\text { (people) }\end{array}$ & Area (Ha) & $\begin{array}{c}\text { Population Density } \\
\text { (people/Ha) }\end{array}$ \\
\hline Pasar Rebo & 221.158 & 1.298 & 17,038 \\
\hline Ciracas & 300.345 & 1.608 & 18,678 \\
\hline Cipayung & 282.360 & 2.845 & 9,924 \\
\hline Makasar & 204.595 & 2.185 & 9,363 \\
\hline Kramat Jati & 298.121 & 1.300 & 22,932 \\
\hline Jatinegara & 275.903 & 1.025 & 26,917 \\
\hline Duren Sawit & 399.595 & 2.265 & 17,642 \\
\hline Cakung & 537.756 & 4.228 & 12,718 \\
\hline Pulo & 266.199 & $1 . .561$ & 17,053 \\
Gadung & 151.827 & 488 & 31,112 \\
\hline Matraman & 2.937.859 & 18.803 & \\
\hline Total & Source: Jakarta Timur Dalam Angka, 2020
\end{tabular}

\section{E. Analysis of Land Classification}

Combination of color composites (composite bands) in the study is Red 7, Green 5, Blue 3 with a basic reason for facilitating researchers to analyze classification of land cover in satellite imagery. The land cover analyzed is divided into 4 land classes, specifically developed land, vegetation, water bodies, and undeveloped land, as can be seen in Figure 2 and Figure 3. The classification method that is used is supervised classification maximum likelihood.

TABLE II. LAND COVER CLASSIFICATION

\begin{tabular}{llllll}
\hline No & $\begin{array}{l}\text { Land } \\
\text { Cover }\end{array}$ & $\mathbf{1 9 9 0}(\mathbf{H a})$ & $\mathbf{2 0 0 0}(\mathbf{H a})$ & $\mathbf{2 0 1 0}(\mathbf{H a})$ & $\mathbf{2 0 2 0}(\mathbf{H a})$ \\
\hline 1 & $\begin{array}{l}\text { Built Up } \\
\text { Area }\end{array}$ & $10.137,06$ & $12.016,08$ & $13.646,86$ & $14.338,22$ \\
\hline 2 & Vegetation & $5.924,43$ & $3.986,64$ & $3.111,81$ & $2.388,53$ \\
\hline 3 & Water Body & $1.531,44$ & $1.885,86$ & $1.191,20$ & $1.280,22$ \\
\hline 4 & $\begin{array}{l}\text { Empty/ dry } \\
\text { Land }\end{array}$ & 947,97 & 652,32 & 592,78 & 535,67 \\
\hline Total & $18.542,66$ & & & \\
\hline
\end{tabular}


Table 2 indicates land cover changing within 4-decade from $1990-2020$. Amongst four variables of the land cover, it is only one variable which shows increasing development area in the significant value - the built-up area. Since the total are is fixed, in general we may see that the others three variable have been decreasing, with one exceptional condition whereby the water body in the period of $1990-$ 2000 had increased at about $23 \%$. Drastically changing has been occurring at the vegetation total area between decades from 1990 - 2020, at about (-) $32,7 \%$, (-) 36,8\%, (+) 7,47\%, respectively.
Value the producer's and user's accuracy of each class can be seen in Table 3 with values $>70 \%$. Based on the calculation of the accuracy test, the value obtained for overall accuracy is $94,62 \%$ and the kappa coefficient value is 0,8999 or $89,99 \%$. The minimum value for receiving a remote sensing-based mapping is $85 \%$, so that the data from the guided classification conducted in the study can be accepted or used [16].

TABLE III.

LAND COVER CONFUSION MATRIX 2020

\begin{tabular}{|c|c|c|c|c|c|c|c|}
\hline \multirow[b]{2}{*}{$\begin{array}{l}\text { Reference Data } \\
\text { (training area) }\end{array}$} & \multicolumn{7}{|c|}{ Reference data (pixels) } \\
\hline & $\begin{array}{l}\text { Built } \\
\text { Area }\end{array}$ & $\begin{array}{l}\text { Vegetatio } \\
\mathrm{n}\end{array}$ & $\begin{array}{l}\text { Empty/ dry } \\
\text { Land }\end{array}$ & $\begin{array}{l}\text { Water } \\
\text { Body }\end{array}$ & $\begin{array}{l}\text { Row } \\
\text { Total }\end{array}$ & $\begin{array}{l}\text { Omission } \\
\text { (pixels) }\end{array}$ & $\begin{array}{r}\text { Producer } \\
\text { accuracy }(\%) \\
\end{array}$ \\
\hline Built Up Area & 5585 & 11 & 11 & 9 & 5616 & $\begin{array}{l}5585 / 561 \\
6\end{array}$ & 99,45 \\
\hline Vegetation & 17 & 1652 & 4 & 57 & 1730 & $\begin{array}{l}1652 / 173 \\
0\end{array}$ & 95,49 \\
\hline Empty/ dry Land & 59 & 19 & 395 & 4 & 477 & $395 / 477$ & 82,81 \\
\hline Water Body & 77 & 209 & 0 & 773 & 1059 & $773 / 1059$ & $72 ., 99$ \\
\hline Column Total & 5738 & 1891 & 410 & 843 & & & \\
\hline $\begin{array}{l}\text { Commission } \\
\text { (pixels) }\end{array}$ & $5585 / 5738$ & $\begin{array}{l}1652 / 189 \\
1\end{array}$ & $395 / 410$ & $773 / 843$ & & & \\
\hline $\begin{array}{l}\text { User's accuracy } \\
(\%)\end{array}$ & 97,33 & 87,36 & 96,34 & 91,70 & & & \\
\hline
\end{tabular}

Source: Analysis Result, 2020
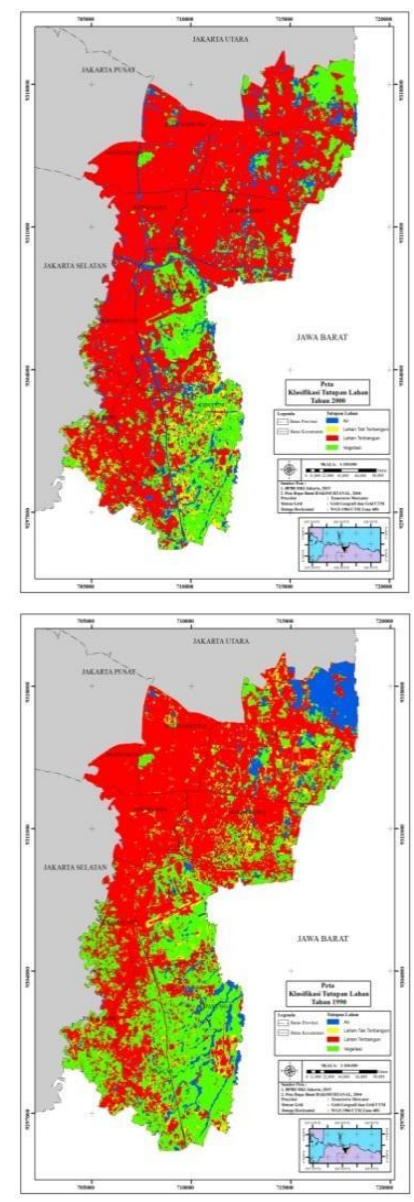

Fig. 2 Land CoveDear Author,

At this time unfortunately our speed post service not available in maharashtra so we send you later by this coronavirus unable to send you. www.ijert.orgr 1990 and 2000

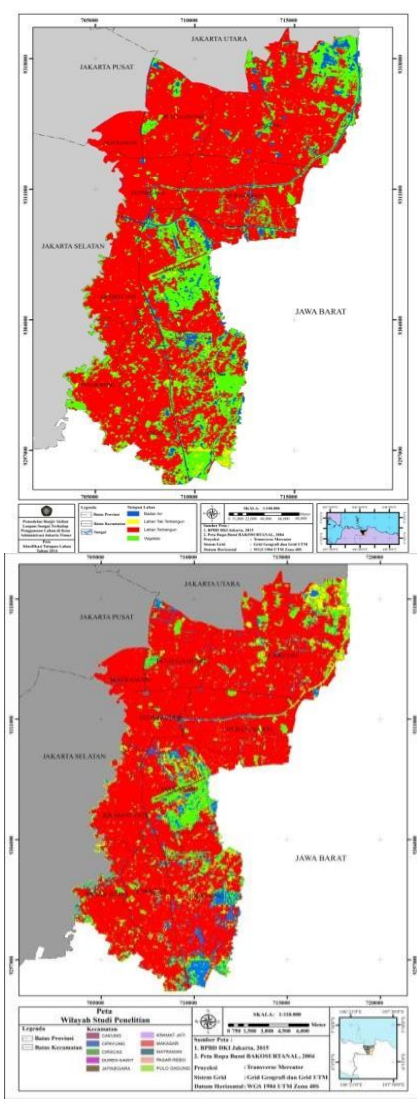

Fig. 3 Land Cover in 2010 and 2020

\section{F. Land Cover Change Analysis (Change Detection)}

Land cover change analysis is carried out to determine the detailed point/location of changes in each land cover using the change detection method in ENVI 5.2 software. 
Detection of change can be divided into two forms, namely, increase and decrease. Data entered to compare land cover changes are two years of data, for example, 1990 and 2020. The auto-thresholding method is Otsu's the results of land change analysis can be seen in Figure 4.

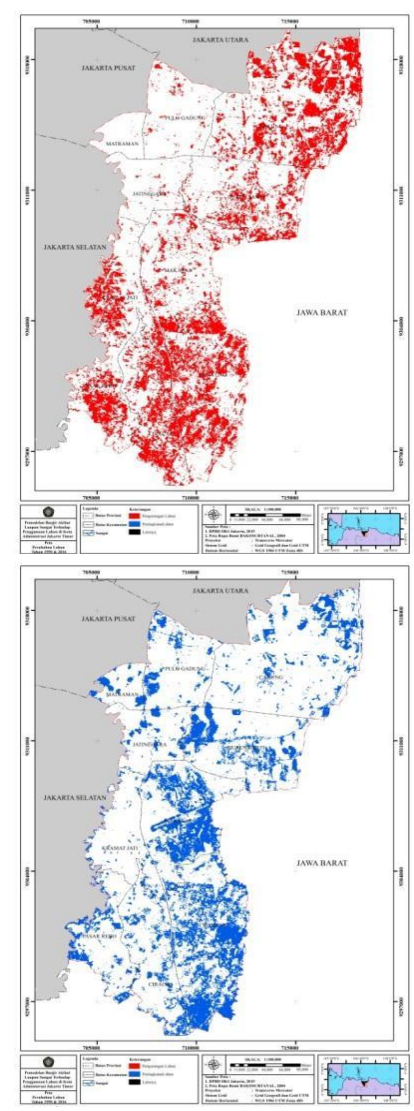

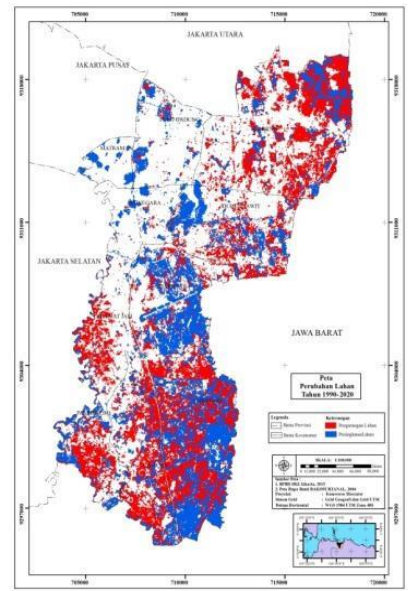

Fig. 4 Map of Land Cover Change 1990-2020

Figure 4 illustrate land cover changes from 1990 - 2020 as a result of auto-thresholding method analysis. The first map with red dots indicates a change inland in the form of land reduction. The second one - blue dots indicates an increase inland. The white color indicates the non-changes of land use. Then, the third map depicts the overlay result. In general, it is indicated that total land cover of built-up area instead of changed to another land use, its area has been getting wider and wider occupied the others.

TABLE IV.

LAND COVER CHANGE

\begin{tabular}{|c|c|c|c|c|c|c|c|c|c|c|}
\hline \multirow[b]{2}{*}{ Land Cover } & \multirow[b]{2}{*}{1990 (ha) } & \multirow[b]{2}{*}{2000 (ha) } & \multirow[b]{2}{*}{2010 (ha) } & \multirow[b]{2}{*}{2020 (ha) } & \multicolumn{6}{|c|}{ Difference in Change } \\
\hline & & & & & $\begin{array}{l}1990- \\
2000\end{array}$ & $\begin{array}{c}\text { percentage } \\
(\%)\end{array}$ & $\begin{array}{l}2000- \\
2010\end{array}$ & $\begin{array}{c}\text { percentage } \\
(\%)\end{array}$ & $\begin{array}{l}2010- \\
2020\end{array}$ & $\begin{array}{c}\text { percentage } \\
(\%)\end{array}$ \\
\hline Built Up Area & 10137.1 & 12016.1 & 13246.9 & 14338.2 & 1879.02 & $18.53(+)$ & 1230.78 & $10.24(+)$ & 1091.36 & $8.24(+)$ \\
\hline Vegetation & 5924.43 & 3986.64 & 4111.81 & 2388.53 & 1937.79 & $32.71(-)$ & 125.17 & $3.13(+)$ & 1723.28 & $41.91(-)$ \\
\hline Water Body & 1531.44 & 1885.86 & 991.2 & 1280.22 & 354.42 & $23.14(+)$ & 894.66 & $47.44(-)$ & 289.02 & $29.15(+)$ \\
\hline $\begin{array}{l}\text { Empty/ dry } \\
\text { Land }\end{array}$ & 947.97 & 652.32 & 192.78 & 535.67 & 295.65 & $31.19(-)$ & 459.54 & $70.45(-)$ & 342.89 & $177.87(+)$ \\
\hline Total & & & & & & & & & & \\
\hline
\end{tabular}

Based on Table 4, land cover of the built-up area from 1990 to 2000 has been increasing significantly at every decade. Even though the number of percentages per decade has been lessening, but the number of built up area has been getting bigger and bigger with percentage of changing at about $18,53 \%, 10,24 \%, 8,24 \%$, respectively. It might assume that land-use change occurred due to continuous growth of population, hence to support their activity the needs of housing settlements and infrastructures also increase.

In general, within four decades, the pattern of land cover of vegetation has been decreasing, except in one period between 2000 and 2010. In the period of 1990-2000, total area of vegetation has been reducing $32.71 \%$ or in other words the total area has been dwindling at about $1,937.79$ Ha within a decade. The reduction of vegetation land appears to be predominantly transformed into developed land or built-up area. The area of vegetation has been increasing slightly in the period 2000-2010 at about $3.13 \%$ or at around of $125.17 \mathrm{Ha}$, due to a significant change from water body at Banjir Kanal Timur into a vegetation area. Particularly, there are several specific locations have unchanged vegetation area, such as Rawamangun Golf Course, Pulo Mas Horse Racing area, city parks, Halim Perdana Kusumah Airport, Taman Mini Indonesia Indah park, Military (TNI) Headquarters building and Cibubur Camping Ground. 


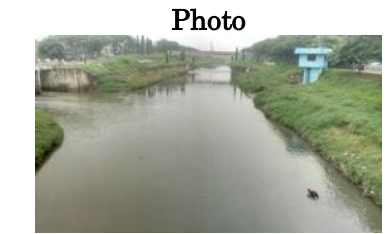

The East Flood Canal functions as a flood controller

Photo

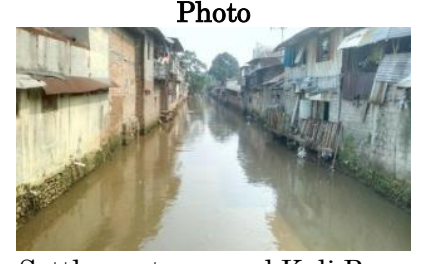

Settlements around Kali Baru Timur
Photo

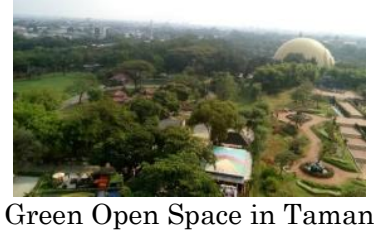
Mini Indonesia Indah

Photo

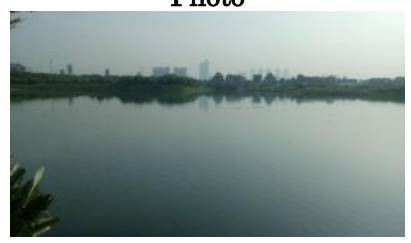

Ria Rio Lake as a catchment area

Figure 5 the existing condition of the study area

The water body in the study is in the form of rivers, reservoirs/lakes, and puddles. Pattern of land cover of the water body tends to be increased, except in the period of 2000-2010. Between 1990-2000, the condition of water bodies has been increasing at around $23.14 \%$ or in other words it became wider at around 354,42 Ha from 1531,44 $\mathrm{Ha}$ (year of 1990) to $1.885,86 \mathrm{Ha}$ (year of 2000). Increases and reductions are influenced by seasonal conditions of the annual image that has been used, it caused total area of the water bodies that mostly in the form of lakes/reservoirs and rivers will also be different. In one hand, decreasing land cover of water body in the period of 2000-2010, it might cause by the changing of reservoir at Banjir Timur Kanal that is covered by vegetation, so that the satellite analysis read the data of 2000 as a vegetation area. On the other hand, within the period of $2000-2010$, Conversely, due to rain pouring there were some puddle points on the road or outside rivers, reservoirs/lakes, that the satellite analysis read it as the water body.

\section{G. Spatial Analysis}

\section{1) Ordinary Least Square (OLS)}

Independent variables $(\mathrm{X})$ that are estimated to have positive or negative linear relationships to the flood height of an area have been analyzed by OLS regression. The height of flood is placed as dependent variable in the regression analysis - labelled as Y. Independent variables that is allowed into the model are only two because in the ArcGIS application requires value of the degree of freedom of the model have to be greater than 2. OLS diagnostics of the best model is as described in Table $\mathrm{V}$.

TABLE V

OLS REGRESSION DIAGNOSTICS

\begin{tabular}{cccccc}
\hline VARIABLE & Coefficient & $\begin{array}{c}\text { Std. } \\
\text { Error }\end{array}$ & Probability & Robust_Pr & VIF \\
\hline $\begin{array}{c}\text { Intercept } \\
\text { Area } \\
\text { Height }\end{array}$ & $-65,662466$ & 32,277274 & 0,097527 & $0,021550^{*}$ & - \\
\hline $\begin{array}{l}\text { Built-up } \\
\text { Area }\end{array}$ & 0,196955 & 0,459584 & $0,047491 *$ & $0,035655^{*}$ & 1,298620 \\
\hline
\end{tabular}

OLS regression analysis results in Table 5 show significant values marked by probability values below 0.05 . The significant value plays a role in testing the results of subsequent regressions.

TABLE VI.

COEFFICIENT VALUE OF INDEPENDENT VARIABLES

\begin{tabular}{ll}
\hline Variable & Coefficient \\
\hline Area Height (X1) & 1,196955 \\
Built-up Area (X2) & 0,115023 \\
\hline
\end{tabular}

Table 6 OLS results show that the height of the region has a negative relationship, while the variable area of builtup has a positive relationship. This means that the greater value of the height of a certain area (X1) indicates the lower the height of the flood. In contrary, the greater value of builtup area (X2) indicates the higher the height of the flood.

TABLE VII. HETEROSKEDASTICITY TEST

\begin{tabular}{ll}
\hline Parameter & Score \\
\hline Koenker BP Statistic & 5,197422
\end{tabular}

The results of heteroskedasticity can be seen in Table 7 that the BP Koenker value is above 0.05. Meaning, in the model, there is no heteroskedasticity and the value of stationary independent variables in each unit of analysis. The significance of the independent variable is seen from the probability value in the model results. However, it should be noted also the figures from Koenker (BP). Values from Koenker (BP)> 0.05 then Robust_Pr is not used. The probability value of the variable height of the area and the area of built land has a probability value above 0.05 then Robust_Pr is used because it has a value below 0.05 which is equal to $0.035655 *$ for the height of the area and $0.020644^{*}$ for the area of the developed land. The multicollinearity value in the model can be seen from the VIF of each variable. In Table 8 , it can be seen that the VIF value of the variables in the model is less than 10 , so there is no multicollinearity among the independent variables [13]. If there is multicollinearity, the variable can be said to be unfavorable because it does not explain anything.

TABLE VIII. VIF VALUE OF EACH VARIABLE

\begin{tabular}{ll}
\hline Variable & Nilai VIF \\
\hline Area Height (X1) & 1,298620 \\
Built-up Area (X2) & 1,298620 \\
\hline
\end{tabular}

The results of multicollinearity can be seen that the VIF values of the two independent variables are below the value of 10. So, there is no multicollinearity in each variable and the resulting model can be used.

Residual is the difference between the existing value and the predicted value of the model. Residual values from OLS modeling must be normally distributed. Because the more the residual value away from the number 0 , the resulting model is not good. The test can be performed with Bell Curve or Jarque-Bera values.

\section{TABLE IX. RESIDUAL NORMALITY TEST}

\begin{tabular}{ll}
\hline Parameter & Score \\
\hline Jarque-Bera Statistic & 0,180144 \\
\hline Table 9 depicts that results of the model residual
\end{tabular}
normality have a Jarque-Bera value with above a significant value of 0.05 [14]. Meaning that the model residuals are normally distributed and there is no bias in the resulting model. Model performance is indicated by adjusted R2 and AICc values. Model performance test results in Cipayung District are as illustrated in Table 10. 
TABLE $X$.

UjI PERFORMA MODEL

\begin{tabular}{ll}
\hline Parameter & Nilai \\
\hline Adjusted R2 & 0,406586 \\
AICc & 79,302217
\end{tabular}

The performance of the model can be seen in Table 10, the adjusted R2 value of the model is $40.65 \%$. It means that $40.65 \%$ of the model has explained the phenomenon of flood height in Cipayung District. The AICc value of the model is 79.30. The greater the value, the better the model will be produced.

From the test results, it can be concluded that the global regression model for flood height variables can be accepted. The following formula exemplifies a global model of flood height in Cipayung District.

$$
\begin{aligned}
& \text { Information: } \\
& \mathrm{Y}=\text { Flood Height } \\
& \mathrm{X} 1=\text { Area Height } \\
& \mathrm{X} 2=\text { Land Area Built }
\end{aligned}
$$$$
Y=-65,662466+1,196955 X 1+0,115023 X 2
$$

The coefficient value of each variable shows how much influence the variable has on the flood height in Cipayung District. From the OLS results, it was found that the greatest influence to minimize the height of flooding that occurred was the height of the region, which amounted to 1,196955 . The relationship between the area of built-up land and flood height is directly proportional. Thus, the higher the value of the area of built-up area, the higher the height of the flooding that is occurred in Cipayung District.

\section{2) Geographically Weighted Regression (GWR)}

The global regression model that has been obtained from the OLS process can be broken down in to local regression model using the GWR method. Calculation of the local model is based on an assumption that the effect of independent variable toward dependent variable will be different at each location [17]. The local model will also able to describe the condition of each village in a better way and it will cover inaccuracy of the global regression model.

TABLE XI. GWR DIAGNOSTICS IN CIPAYUNG DISTRICT

\begin{tabular}{ccccc}
\hline Subdistrict & $\begin{array}{c}\text { Flood Height } \\
\text { Observation } \\
\text { Value (y) }\end{array}$ & $\begin{array}{c}\text { Flood } \\
\text { Height } \\
\text { Prediction } \\
\text { Value }(\widehat{\boldsymbol{y} \boldsymbol{y})}\end{array}$ & $\begin{array}{c}\text { Residual } \\
\text { Value }\end{array}$ & $\begin{array}{c}\text { Residual } \\
\text { Standard } \\
\text { Value }\end{array}$ \\
\hline Munjul & 16,796 & 16,921 & $-16,921$ & $-1,759$ \\
Pondok & 16,796 & 24,816 & 15,183 & 1,832 \\
Ranggon & & & & \\
Cipayung & 16,793 & 9,231 & $-9,231$ & $-0,865$ \\
Cilangkap & 16,792 & 17,532 & 2,467 & 0,257 \\
Setu & 16,789 & $-5,223$ & 5,223 & 0,560 \\
Ceger & 16,790 & $-2,413$ & 2,413 & 0,268 \\
Bambu Apus & 16,790 & $-3,122$ & 3,122 & 0,315 \\
Lubang & 16,787 & 2,274 & $-2,274$ & $-0,463$ \\
Buaya & & & &
\end{tabular}

Table 11 shows the predicted value of flood height that is obtained by entering the observation value of the independent variable into the model. The difference between the observed value and the predicted value is the residual value which is then standardized into the residual standard value. Residual standard values must be randomly distributed. If the residual standard values appear to be clustered, spatial autocorrelation occurs and the resulting GWR model is not good.

TABLE XII. COEFFICIENT ESTIMATION FOR EACH SUBDISTRICT IN CIPAYUNG DISTRICT

\begin{tabular}{cccc}
\hline Subdistrict & $\begin{array}{c}\text { Local } \\
\text { Intercept }\end{array}$ & X1 (Area Height) & $\begin{array}{c}\text { X2 (Land Area } \\
\text { Built) }\end{array}$ \\
\hline Munjul & 57,58 & 1,197 & 0,115 \\
Pondok & 57,60 & 1,197 & 0,115 \\
Ranggon & & & \\
Cipayung & 57,59 & 1,196 & 0,115 \\
Cilangkap & 57,60 & 1,196 & 0,115 \\
Setu & 57,61 & 1,196 & 0,114 \\
Ceger & 57,59 & 1,195 & 0,114 \\
Bambu Apus & 57,60 & 1,195 & 0,114 \\
Lubang Buaya & 57,61 & 1,195 & 0,114 \\
\hline
\end{tabular}

Table 12 shows that there are some differences in the value of the coefficient of altitude in each sub-district. Meaning that the results give an idea of which areas are contributing more to the high and low floods of an area. In summarize, the greater the coefficient value, the lower the height of the flood.

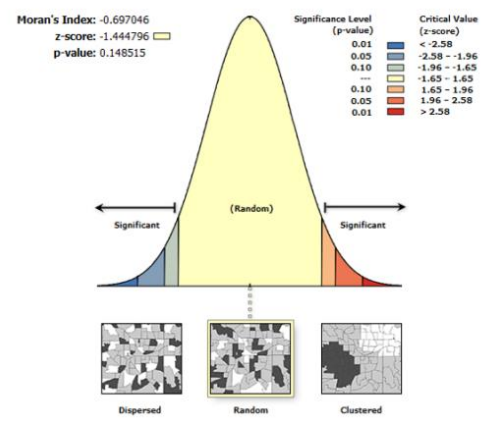

Figure 6 Spatial Autocorrelation Test Results in Cipayung District

The spatial autocorrelation test of the GWR model in Figure 5 uses the formula from Moran's I. The desired result of the test is a randomly distributed residual standard value. When it is viewed from the results of the spatial autocorrelation test presented in the figure, it appears that the standard residuals in the GWR model have been spread evenly with a significance value of 0.148 and a $\mathrm{z}$-score of 1.444. The data from the spatial autocorrelation test concluded that the resulting model is valid and can be used.

Figure 6.1 illustrates that an area with red color indicates that the model is influenced by the height of area (X1), wherein the lower of the flood in case the area is in the form of un-built-up. Figure 6.2 indicates total of the built-up area (X2), whereby the redder indicates the wider built-up area, so the height of flood is also higher. In general, the model gives an information that the height of the area (X1) do not functionally well in order to flow rainfall to the lower places, due to dense area at the upper stream. The areas indicated by circle A and B lies in the height of altitude and dense builtup areas, that are indicated as areas with high puddle.

Therefore, the global model can be used as a reference in seeing the effect of the variable area of land developed and the height of the area on the height of the flood. 


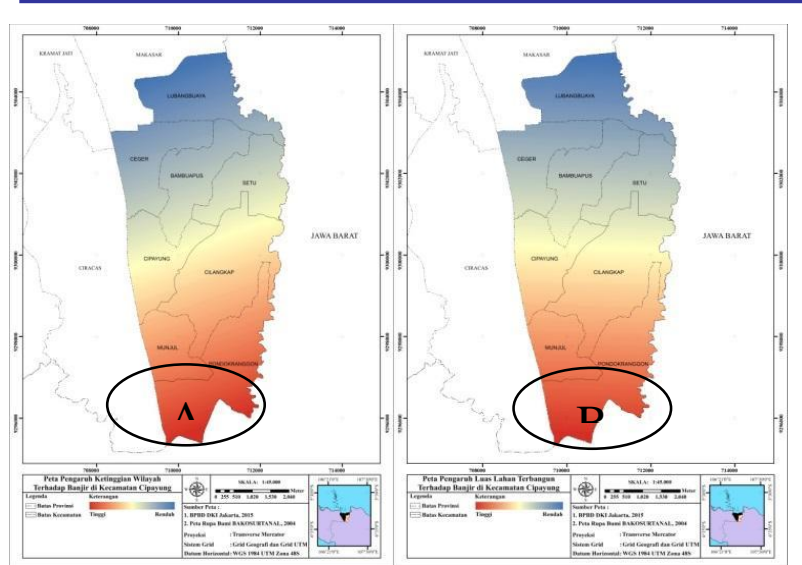

Figure 7 Map of the Influence of Area Altitude and Land Area Built on Flood Height

\section{CONCLUSION}

Due to the growth of population, the condition of land cover in the East Jakarta City in the period of 1990-2020 had a significant changed, especially for increasing of the land cover of built-up area. Since total of the area is fixed, the wider built-up area means the lessen areas for other land uses such as vegetation, water body and un-built-up areas.

The results of OLS and GWR analyzes might give a specific note of the variables that affect flooding at each district, as follows.
a. Cakung District : the height of the region
b. Ciracas District : area of land developed
c. Cipayung District : the height of the area and the size of the developed land
d. Duren Sawit District: land area developed
e. Jatinegara District : population density
f. Kramat Jati District : altitude and rainfall
g. Makasar District : the height of the region
h. Matraman District : rainfall
i. Pasar Rebo District : population density
j. Pulo Gadung District: altitude and rainfall

Knowing each cause of flooding due to research of change detection of land cover might give a better approach on dealing with flooding in a certain area, so that the planning process might heading to the correct direction. Hence, for the future research, result of the research gives a quite significant input in order to develop a more appropriate flood management disaster strategy in the level of both district as well as city level.

\section{ACKNOWLEDGMENT}

Special thanks address to the Regional Disaster Management Agency and the Jakarta Central Statistics Agency for providing the data, as well as for the people who have been willing to be interviewed for this research activity.

\section{REFERENCES}

Books

[1] Jakarta Timur Dalam Angka Tahun 2020. Badan Pusat Statistik Kota Jakarta Timur

[2] Rencana Penanggulangan Bencana Tahun 2013-2017. Badan Penanggulangan Bencana Daerah Provinsi DKI Jakarta.

[3] Data Indeks Risiko Bencana Indonesia Tahun 2018. Badan Nasional Penanggulangan Bencana

[4] Pola Pengelolaan Sumber Daya Air Wilayah Sungai CidanauCiujung-Cidurian-Cisadane-Ciliwung-Citarum Tahun 2012. Kementerian Pekerjaan Umum

\section{Journal}

[5] Akmalah, E., \& Grigg, N. S. (2011). Jakarta Flooding : systems study of socio-technical forces. Water International, 36 (6), 733-747. (2012). BBWSCC. Pola Pengelolaan Sumber Daya Air Wilayah Sungai.

[6] Takagi, H., Esteban, M., Mikami, T., Fujii, D. (2016). Projection of Coastal Floods in 2050 Jakarta. Urban Climate, Vol. 17: 135-145.

[7] Sagala, S., Lassa, J.A., Yasaditama, H., Hudalah, D. (2013). The Evolution of Risk and Vulnerability in Greater Jakarta: contesting government policy in dealing with a megacity's exposure to flooding. IRGSC Working Paper, No.2 (18 pp).

[8] Oppusunggu, R. E. and Tantular, R. (2015). Creating People's Awareness and Pushing Active Contribution. Case: Wider Public Engagement on Flood and Land Use Problems in Jakarta and Surroundings. Procedia- Social and Behavioral Sciences, 184: 240244.

[9] Lillesand, T. M., \& Kiefer, R. W. (1994). Remote Sensing and Image Interpretation, Third Edition, John Wiley \& Son Inc. New York.

[10] Pedroni. (2003). Improved Classification of Landsat Thematic Mapper Data Using Modified Prior Probabilities in Large and Complex Landscape. International Journal of Remote Sensing, 91113.

[11] Hasyim, AW., Gusti, HIK., Prayitno, G., (2020). Determination Of Land Cover As Landslide Factor Based On Multitemporal Raster Data In Malang Regency. International Journal of GEOMATE 18 (69), 254-261

[12] Wasil, A.R., dan Ainun, P.W. (2012). Modelling Land-Use Change. Bandung: Institut Teknologi Bandung

[13] Otsu, N. (1979). A threshold selection method from gray-level histograms. IEEE. Trans Systems Man Cybernet. Vol. 9, pp. 62-66

[14] Mitchell, A. (2005). The ESRI Guide to GIS Analysis, Volume 2. California: ESRI Press

[15] Profil Kotamadya Jakarta Timur, 2003

[16] Jaya, I. N. S. (2010). Analisis Citra Digital : Perspektif Penginderaan Jauh Untuk Pengelolaan Sumber Daya Alam. Bogor: IPB Press..

Fotheringham, A. S., Charlton, M. E., \& Brundson, C. (1998). Geographically Weighted Regression: A Natural Evolution of the Expansion Method for Spatial Data Analysis. Environment and Planning A, 30 (11), 1905-1927

\section{DOCUMENTATION OF ACTIVITIES}

The following is a photo of the documentation carried out during a ground check, to obtain a sample training area so that when conducting supervised classification according to field conditions. Also, to get information related to flooding by asking the community in the surrounding settlements. 